\title{
Analisis Faktor-Faktor yang Mempengaruhi Kesempatan Kerja di Provinsi Jawa Tengah Tahun 1991-2020
}

\author{
Analysis of Factors Influencing Job Opportunities \\ In Central Java Province 1991-2020
}

\author{
Ridwan Fajar Hidayat, Sudati Nur Sadiah \\ Fakultas Ekonomi, Universitas Tidar, Magelang
}

\begin{tabular}{|c|c|}
\hline Info Artikel & Abstrak \\
\hline $\begin{array}{l}\text { Kata Kunci: } \\
\text { Angkatan Kerja } \\
\text { Kesempatan Kerja } \\
\text { Pembangunan Ekonomi } \\
\text { Upah }\end{array}$ & $\begin{array}{l}\text { Peningkatan jumlah tenaga kerja di Provinsi Jawa Tengah } \\
\text { menjadi salah satu tujuan penelitian ini dalam menganalisis } \\
\text { peran PDRB, angkatan kerja, dan UMP dalam upaya } \\
\text { peningkatan kesempatan kerja selama periode 1991-2020. } \\
\text { Penelitian ini menggunakan model regresi linier berganda } \\
\text { dengan metode uji asumsi klasik dan uji statistik yang terdiri } \\
\text { dari Uji t, Uji f, dan uji koefisien determinasi }\left(R^{2}\right) \text {. Hasil } \\
\text { penelitian menunjukan pengaruh kearah positif antara PDRB } \\
\text { dan pertumbuhan UMP dengan kesempatan kerja. } \\
\text { Selanjutnya, variabel angkatan kerja memiliki pengaruh yang } \\
\text { signifikan ke arah negatif dalam meningkatkan tingkat } \\
\text { kesempatan kerja. Temuan lainnya adanya pengaruh antara } \\
\text { variabel PDRB, angkatan kerja dan pertumbuhan UMP dalam } \\
\text { meningkatkan tingkat kesempatan kerja Jawa Tengah selama } \\
\text { periode 1991-2020. Perlu dikaji faktor-faktor lain yang dapat } \\
\text { mempengaruhi kesempatan kerja di Jawa Tengah antara lain } \\
\text { suku bunga, investasi, jumlah perusahaan, nilai produksi dan } \\
\text { lain sebagainya. }\end{array}$ \\
\hline & Abstract \\
\hline $\begin{array}{l}\text { Keywords: } \\
\text { Economic Development } \\
\text { Job Opportunities } \\
\text { Labor Force } \\
\text { Wages }\end{array}$ & $\begin{array}{l}\text { The increase in the number of workers in Central Java } \\
\text { Province is one of the objectives of this study in analyzing the } \\
\text { role of GRDP, the workforce, and the UMP in an effort to } \\
\text { increase job opportunities during the period } 1991-2020 \text {. This } \\
\text { research uses multiple linear regression model with classical } \\
\text { assumption test method and statistical test consisting of t test, } \\
\text { f test, and coefficient of determination test }\left(R^{2}\right) \text {. The results of } \\
\text { the study show a positive influence between GRDP and UMP } \\
\text { growth with job opportunities. Furthermore, the labor force } \\
\text { variable has a significant negative effect in increasing the } \\
\text { level of employment opportunities. Another finding is that } \\
\text { there is an influence between the variables of GRDP, labor } \\
\text { force and UMP growth in increasing the level of employment } \\
\text { in Central Java during the period 1991-2020. It is necessary } \\
\text { to study other factors that can affect employment } \\
\text { opportunities in Central Java, including interest rates, } \\
\text { investment, number of companies, production value and so on. }\end{array}$ \\
\hline
\end{tabular}

http://ejournal.bappeda.jatengprov.go.id/index.php/jurnaljateng 


\section{PENDAHULUAN}

Kesejahteraan masyarakat adalah tujuan utama dari kebijakan pembangunan ekonomi dengan harapan taraf hidup masyarakat semakin meningkat dan tingkat kesempatan kerja yang tinggi serta mengurangi ketimpangan pendapatan masyarakat di suatu daerah. Dalam melihat perkembangan pembangunan ekonomi, angka pengangguran digunakan sebagai salah satu indikator perekonomian. Tingkat pengangguran yang tinggi disebabkan karena jumlah angkatan kerja terus meningkat tetapi jumlah kesempatan kerja tidak berubah atau tetap pada jumlah yang sama sehingga menimbulkan ketidak-seimbangan dalam pasar kerja, maka akan berdampak terhadap pertumbuhan ekonomi nasional (Pratama \& Hadiyanti, 2020).

Kesempatan kerja menjadi salah satu masalah penting dalam pembangunan ekonomi dimana jumlah tenaga kerja meningkat dari tahun ke tahun di berbagai daerah termasuk di Jawa Tengah. Peningkatan jumlah tenaga di Provinsi Jawa Tengah dapat dilihat dalam gambar dibawah ini:

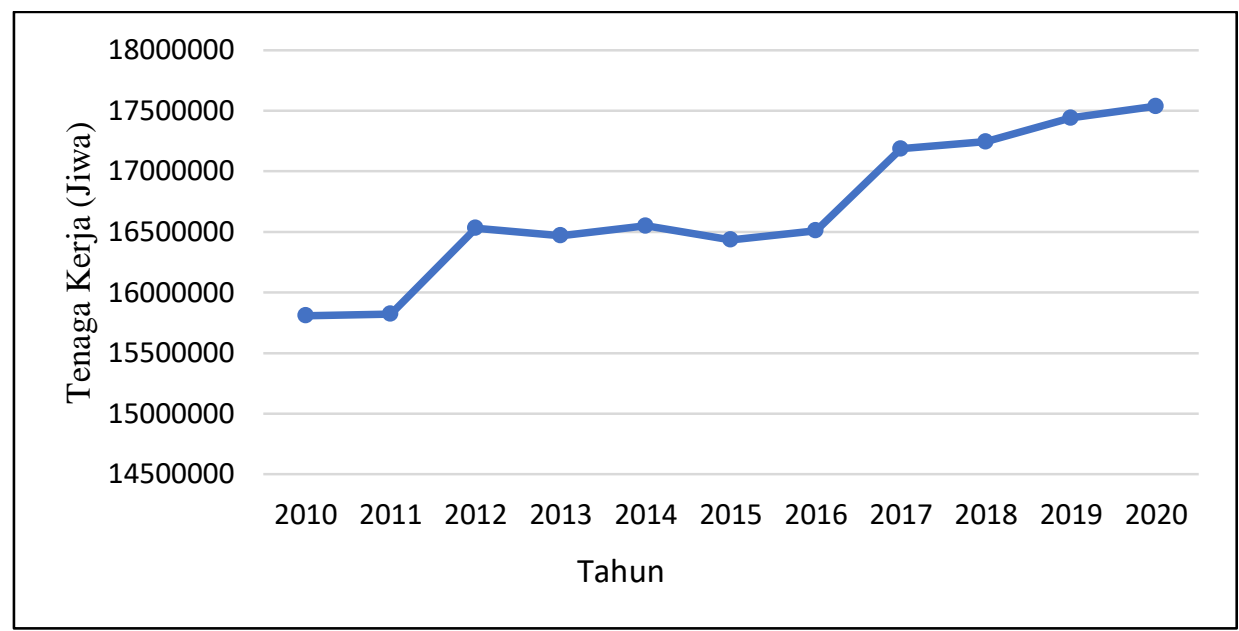

Gambar 1: Perkembangan jumlah tenaga kerja di Provinsi Jawa Tengah Sumber: BPS Provinsi Jawa Tengah. (Diolah)

Berdasarkan gambar 1 di atas, jumlah tenaga kerja di Provinsi Jawa Tengah selama 10 tahun terakhir menunjukkan tren peningkatan. Peningkatan jumlah tenaga kerja dalam suatu daerah akan menimbulkan dampak dalam bidang ketenagakerjaan. Hal tersebut selanjutnya berdampak pula terhadap pelak-sanaan pembangunan daerah. Untuk meng-atasi masalah ekonomi diperlukan pembangu-nan, khususnya di bidang ketenagakerjaan yang pada dasarnya untuk meningkatkan kesejahteraan masyarakat. BPS Jawa Tengah mencatat pada tahun $2020,70,6 \%$ penduduk Jawa Tengah berada dalam usia produktif. Bonus demografi yang berlangsung tersebut tidak berdampak banyak terhadap pertum-buhan Jawa Tengah, hal ini akibat kurangnya penyerapan tenaga kerja di Jawa Tengah di- mana Tingkat Pengangguran Terbuka (TPT) sebesar $6,48 \%$.

Jumlah tenaga kerja menjadi faktor penting dan potensial dalam meningkatkan perekonomian daerah karena jumlahnya yang cukup besar di Indonesia terutama Provinsi Jawa Tengah sehingga berpotensi memper-cepat laju pembangunan daerah secara keseluruhan. Menurut Herlina (2016), dam-pak yang ditimbulkan akibat meningkatnya laju pertumbuhan ekonomi dan pembangunan dalam suatu daerah adalah meningkatkan jumlah permintaan tenaga kerja sehingga penyerapan tenaga kerja juga bertambah. Namun ketika pertumbuhan penduduk sema-kin besar, hal tersebut akan membuat kebu-tuhan terhadap lapangan pekerjaan semakin besar. Kesempatan kerja dapat diartikan seba-gai jumlah lapangan kerja yang sudah terisi oleh tenaga kerja 
maupun yang belum terisi oleh tenaga kerja (Saputra et al., 2021). Terkait dengan kesempatan kerja, Danawati et al., (2016) mengemukakan bahwa kesem-patan kerja tercipta dari adanya perkem-bangan kegiatan ekonomi dalam suatu daerah (regional). Penelitian Sari, Musa dan Lestari (2017) yang berjudul Pengaruh Tingkat Pendidikan Dan Upah Serta Jumlah Ang-katan Kerja Terhadap Kesempatan Kerja mengemukakan hasil bahwa kesempatan kerja dipengaruhi oleh tingkat pendidikan, upah dan jumlah angkatan kerja, dimana angkatan kerja memiliki pengaruh yang negatif dan signifikan terhadap kesempatan kerja di Kota Samarinda. Teori ekonomi regional menyatakan bahwa ketika suatu sektor mengalami pertumbuhan ekonomi maka kesempatan kerja dalam sektor tersebut juga akan meningkat. Pertumbuhan ekonomi yang tinggi akan meningkatkan tingkat penyerapan tenaga kerja dalam pasar kerja, dengan kata lain terdapat hubungan yang erat dalam meningkatkan pertumbuhan ekonomi de-ngan penyerapan tenaga kerja. Menurut Alisman (2018), penyerapan tenaga kerja dipengaruhi oleh pertumbuhan perekonomian di suatu daerah. Dalam skala perekonomian daerah, peningkatan atau pertumbuhan PDRB digunakan sebagai indikator dalam meng-ukur perkembangan perekonomian daerah (Wahyuni, 2019). Pertumbuhan PDRB men-jadi salah satu indikator penting dalam perekonomian daerah karena mengindika-sikan atau menggambarkan keadaan per-ekonomian di daerah tersebut pada tahun tertentu. Pertumbuhan PDRB diukur berda-sarkan nilai PDRB riil tahun tertentu dibandingkan dengan nilai PDRB riil tahun sebelumnya. Penelitian yang dilakukan oleh Pratama \& Hadiyanti (2020) dari artikelnya yang berjudul Pengaruh Produk Domestik Regional Bruto terhadap Kesempatan Kerja di Provinsi Kalimantan Timur, menyatakan bah-wa kesempatan kerja di Kalimantan Timur dipengaruhi oleh PDRB dengan menunjukkan hasil yang positif dan signifikan. Penelitian lain yang dilakukan oleh Pangastuti (2015) mengemukakan hasil bahwa PDRB memiliki hubungan ke arah negatif dan signifikan ter-hadap kesempatan kerja di Jawa Tengah.

Menurut Atiyatna et al., (2016) keseimbangan dalam pasar kerja (penawaran dan permintaan tenaga kerja) memiliki kaitan terhadap penyerapan tenaga kerja, maka secara simultan akan menentukan tingkat upah keseimbangan dan pengangguran tenaga kerja keseimbangan. Permintaan tenaga kerja ialah jumlah te-naga kerja yang terserap dalam pasar kerja yang artinya permintaan tenaga kerja akan menimbulkan jumlah penduduk yang bekerja akan mengalami peningkatan (Hermawan et al., 2017). Selain meningkatnya jumlah tenaga kerja, fenomena tenaga kerja murah menjadi persoalan yang harus diselesaikan. Menurut Badan Pusat Statistik Jawa Tengah, rata-rata upah bersih yang diterima tenaga kerja dengan rentang usia 15-19 tahun yaitu Rp1.428.755,- per bulan sementara upah tertinggi diterima oleh pekerja rentang usia 55-59 tahun dengan upah rata-rata Rp.2.853.230,- per bulan.

Pandangan dalam teori ekonomi NeoKlasik menyatakan ketika penawaran terhadap tenaga kerja meningkat maka upah yang dikeluarkan oleh produsen juga meningkat. Sebaliknya, akan terjadi penurunan permintaan tenaga kerja ketika upah mengalami peningkatan. Menurut Sugiharti dan Kurnia (2018), permintaan terhadap tenaga kerja harus memperhatikan faktor upah dan faktor tenaga kerja yang tersedia. Penawaran tenaga kerja yang meningkat memberikan dampak terhadap keseimbangan permintaan dan pena-waran tenaga kerja. Penawaran kerja tinggi namun belum mampu terserap dalam lapa-ngan kerja akibat dari tingkat kesempatan kerja yang rendah akan menimbulkan pe-ngangguran. Pada sektor formal, dalam peme-nuhan pada hasil uji statistik dimana ketika statistiknya berada dalam area tolak maka dikatakan signifikan, sebaliknya apabila sta-tistiknya berada diluar area tolak maka hasilnya dinyatakan tidak diterima. Hipotesis yang digunakan yaitu: 
H0 : Secara parsial variabel independen tidak memiliki pengaruh terhadap variabel dependen.

H1 : Secara parsial variabel independen memiliki pengaruh terhadap variabel dependen.

Uji F-statistik bertujuan mendeteksi ada tidaknya pengaruh dari variabel independen terhadap variabel dependen secara simultan. Hasil yang signifikan memiliki arti bahwa secara simultan terdapat pengaruh atau memiliki hubungan. Pemilihan taraf signi-fikansi atau derajat kepercayaan adalah berbeda atau beragam, sesuai keputusan peneliti. Terdapat 3 opsi dalam pemilihan taraf signifikansi yaitu $\alpha=0.01(1 \%), \alpha=$ 0.05 (5\%), dan $\alpha=0.10$ (10\%) (Gujarati dan Porter, 2013; 309-310). Taraf signifikansi yang digunakan dalam penelitian ini yaitu $\alpha$ $=0.05(5 \%)$. Hipotesis dalam uji-F statistik yaitu:

HO :variabel independen tidak memiliki pengaruh secara simultan terhadap variabel dependen.

H1 :variabel independen memiliki pengaruh secara simultan terhadap variabel dependen.
Uji koefisien determinasi $\left(\boldsymbol{R}^{\mathbf{2}}\right)$. Dalam mengukur goodness of fit, dalam sebuah regresi standar ukuran yang umum digunakan adalah besarnya nilai koefisien determinasi atau $R^{2}$ (Gujarati dan Porter, 2013: 97). Hasil koefisien determinasi menunjukkan tingkat atau besaran presentase keberpengaruhan di antara variabel independen (bebas) terhadap variabel dependen (terikat). Besaran persentase pengaruhnya dihasilkan dari nilai Adjusted- $R^{2}$ yaitu antara 0 hingga $1\left(0 \leq R^{2} \leq 1\right)$. Apabila nilai yang dihasilkan oleh Adjusted- $R^{2}$ mendekati angka 1 dapat diartikan variabel independen memiliki pengaruh yang semakin baik terhadap variabel dependen.

\section{HASIL DAN PEMBAHASAN}

\section{Hasil Penelitian}

Uji Normalitas. Tujuan dari uji normalitas adalah untuk mendeteksi residual atau error berdistribusi normal. Apa-bila nilai probabilitas Jarque Bera $>\alpha=0.05$, maka dapat dikatakan model memenuhi asumsi normalitas. Hasil uji normalitas, jarque bera memiliki nilai di atas $\alpha=0.05$ yaitu sebesar 0.547006 dengan nilai probabilitasnya se-besar 0.760710 sehingga model memenuhi asumsi normalitas.

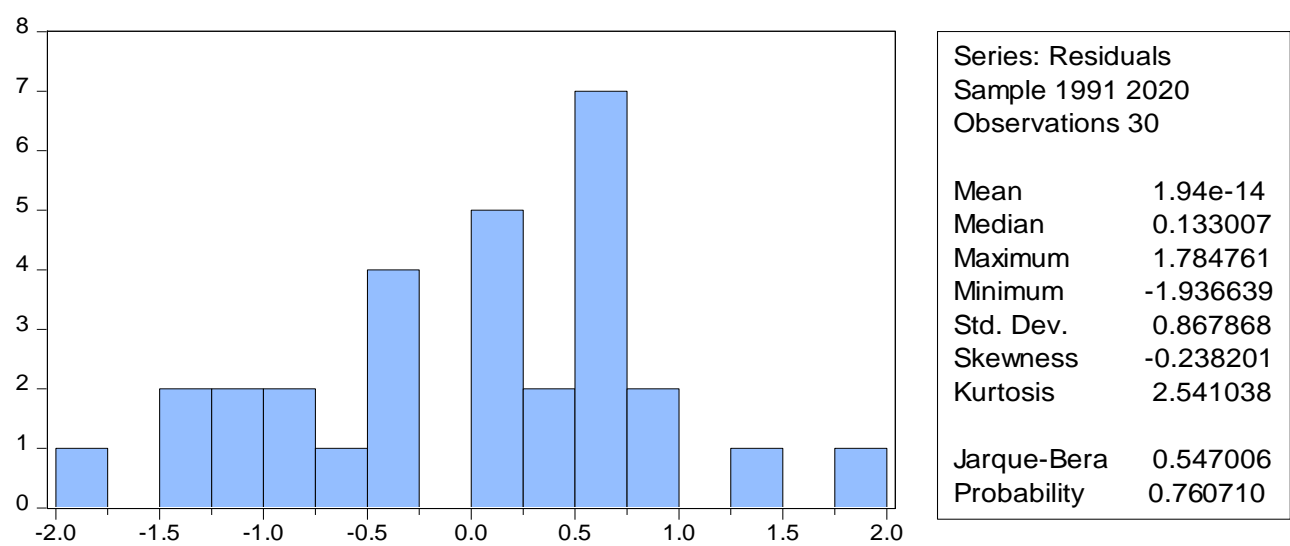

Gambar 2: Hasil Uji Normalitas

Sumber: Hasil Olah Data Eviews 10. (2021)

Uji Autokorelasi. Bertujuan mendeteksi masalah autokorelasi dalam model. Deteksi masalah autokorelasi meng-gunakan Breusch - Godfrey Serial Corre-lation LM Test. Setelah dilakukan uji autokorelasi didapat nilai Prob.Chi-Square 0.9630 sehingga nilai tersebut lebih besar dari derajat keyakinan $\alpha=5 \%$, maka dapat disimpulkan bahwa tidak terjadi korelasi antar variabel dalam penelitian ini. 
Tabel 1.

Hasil Uji Autokorelasi

Breusch-Godfrey Serial Correlation LM Test:

\begin{tabular}{llll}
\hline \hline F-statistic & 0.030208 & Prob. F(2,24) & 0.9703 \\
Obs*R-squared & 0.075331 & Prob. Chi-Square(2) & 0.9630 \\
\hline \hline
\end{tabular}

Sumber : Hasil Olah Data Eviews 10. (2021)

Uji Heteroskedastisitas. Tujuannya mendeteksi apakah terdapat residual dengan varian konstan atau tidak di dalam model penelitian. Ketika dalam hasil pengujian terdapat residual yang sama maka terdapat homoskedastisitas. Sebaliknya, dikatakan terdapat heteroskedastisitas apabila residual memiliki perbedaan. Hasil menunjukkan nilai prob. Chi-Square(3) untuk $O b s^{*} R$-square sebesar 0.0737 sehingga didapat hasil yang lebih besar dari derajad keyakinan atau signifikansi $\alpha=5 \%$.

Berdasarkan hasil yang diperoleh, artinya data dalam penelitian ini memiliki varian residual yang bersifat konstan atau sama sehingga, dapat disimpulkan model tidak terdapat masalah heteroskedastisitas dengan hasil output sebagai berikut:

Tabel 2.

Hasil Uji Heteroskedastisitas

Heteroskedasticity Test: Breusch-Pagan-Godfrey:

\begin{tabular}{llll}
\hline \hline F-statistic & 2.610789 & Prob. F(3,26) & 0.0723 \\
Obs*R-squared & 6.945154 & Prob. Chi-Square(3) & 0.0737 \\
Scaled Explained SS & 4.019476 & Prob. Chi-Square(3) & 0.2594 \\
\hline \hline
\end{tabular}

Sumber : Hasil Olah Data Eviews 10. (2021)

Uji Multikolinearitas. Pengujian multi-kolinearitas digunakan untuk menguji ada tidaknya hubungan secara linier di antara variabel independen (variabel bebas) dalam penelitian, dengan tujuan tidak ada korelasi dalam model di setiap variabel independen yang digunakan. Nilai dari Variance Inflation Factor (VIF) adalah nilai yang menunjukkan hubungan korelasi diantara variabel bebas yang digunakan. Apabila nilai Variance Inflation Factor (VIF) memiliki nilai < 10 (kurang dari 10) maka tidak terdapat hubungan secara linier di antara variabel independen yang digunakan. Hasil uji multikolinearitas dalam penelitian ini menghasilkan nilai Variance Inflation Factor (VIF) kurang dari 10 sehingga dalam penelitian ini tidak memiliki gejala multikolinearitas atau hubungan secara linier di antara variabel independen yang digunakan.

Tabel 3.

Hasil Uji Multikolinearitas

\begin{tabular}{ccc}
\hline \hline Variable & $\begin{array}{c}\text { Centered } \\
\text { VIF }\end{array}$ & Keterangan \\
\hline \hline PDRB & 5.554659 & Tidak Terdapat Korelasi \\
AK & 5.894867 & Tidak Terdapat Korelasi \\
WAGE & 1.299915 & Tidak Terdapat Korelasi \\
C & NA & \\
\hline \hline
\end{tabular}

Sumber: Hasil Olah Data Eviews 10. (2021) 
Tabel 4.

Hasil Regresi Berganda

Variabel Independen : TKK

Metode : Least Squares

\begin{tabular}{lrrr}
\hline \hline \multicolumn{1}{c}{ Variable } & Coefficient & t-Statistic & Prob. \\
\hline \hline PDRB & $9.00 \mathrm{E}-06$ & 4.999838 & 0.0000 \\
AK & -0.001628 & -5.610164 & 0.0000 \\
WAGE & 0.044871 & 2.404106 & 0.0236 \\
C & 115.4174 & 29.13391 & 0.0000 \\
\hline \hline R-squared & 0.655242 & & \\
Adjusted R-squared & 0.615462 & & \\
F-statistic & 16.47173 & & \\
Prob(F-statistic) & 0.000003 & & \\
\hline \hline
\end{tabular}

Sumber: Hasil Olah Data Eviews 10. (2021)

\section{Analisis dan Pembahasan}

Output hasil olah eviews 10, dengan metode OLS (Ordinary Least Square) adalah seperti di bawah ini:

Persamaan regresi yang diperoleh berdasarkan output pada tabel 4 sebagai berikut:

$\mathrm{Y}=115.4174+0.00000900 X_{1}-$ $0.001628 X_{2}+0.044871 X_{3}+\mathrm{e}_{t}$

Dimana:

$Y \quad=$ Tingkat Kesempatan Kerja (\%)

$X_{1} \quad=$ Produk Domestik Regional Bruto (juta rupiah)

$X_{2} \quad=$ Angkatan Kerja (Ribu jiwa)

$X_{3} \quad=$ Laju Pertumbuhan UMP (\%)

e $\quad=$ Error term

Nilai koefisien dapat diinterpretasikan sebagai berikut, $\alpha=115.4174$ artinya ketika PDRB, Angkatan Kerja dan Upah Minimum Provinsi dianggap tetap, maka kesempatan kerja sebesar 115.4174.

Uji t-statistik. Pengujian t-statistik bertujuan mengetahui secara parsial pengaruh dari PDRB, angkatan kerja, dan pertumbuhan UMP terhadap kesempatan kerja. Dari hasil uji t-statistik, variabel PDRB memiliki nilai sebesar 4.999838 dengan nilai probabili-tasnya 0.0000 . Nilai tersebut di bawah taraf signifikansi $\alpha=5 \%$ (0.05) maka secara parsial variabel PDRB memiliki pengaruh yang posi-tif dan signifikan terhadap tingkat kesempatan kerja. Variabel Produk Domestik Regional Bruto (PDRB) memiliki nilai coefficient sebesar 0.0000090 yang berarti ketika PDRB di Provinsi Jawa Tengah meningkat satu juta rupiah dengan ketentuan bahwa angkatan kerja dan UMP konstan akan memiliki dampak terhadap kenaikan tingkat kesempatan kerja sebesar $0.00000900 \%$. Hasil yang didapat sesuai hipotesis awal dimana PDRB memiliki hubungan terhadap kesempatan kerja sehingga hipotesis dinyatakan diterima.

PDRB di Jawa Tengah berpengaruh positif signifikan, dikarenakan Produk Domestik Regional Bruto setiap tahun mengalami peningkatan, dalam hal ini jumlah dari total output atau barang yang diproduksi di Jawa Tengah mengalami penambahan maka produsen akan meningkatkan permintaan terhadap tenaga kerja. Pertumbuhan PDRB memiliki kaitan erat dengan kesempatan kerja yang selalu mengalami perubahan dari waktu ke waktu, hal tersebut berkaitan dengan perekonomian yang sedang terjadi di suatu daerah sehingga, kesempatan kerja berkaitan erat dengan perubahan ekonomi. PDRB Jawa Tengah adalah cerminan dari pertumbuhan ekonomi yang terjadi di Jawa Tengah, apa-bila PDRB mengalami peningkatan maka jumlah kesempatan kerja yang ada di Jawa Tengah juga semakin meningkat dan begitu pula sebaliknya. Nilai PDRB Jawa Tengah selalu mengalami 
peningkatan setiap tahun-nya. Pertumbuhan PDRB tersebut akibat dari kondisi perekonomian yang semakin mem-baik, adanya investasi baik asing maupun dalam negeri serta peraturan pemerintah dan lainnya.

Wilayah Jawa Tengah yang luas dan subur menjadikan penghasil sektor pertanian yang besar. Selain dari sektor pertanian, beberapa wilayah di Jawa Tengah saat ini sedang memajukan sektor pariwisata dengan harapan dapat membuka lapangan kerja baru dalam sektor tersebut sehingga meningkatkan kesempatan kerja di Jawa Tengah. Penelitian ini mendukung penelitian Pratama \& Hadiyanti (2020), dimana hasil penelitiannya mengemukakan terdapat pengaruh yang positif dan signifikan antara PDRB terhadap kesempatan kerja.

Variabel angkatan kerja menghasilkan nilai $t$-statistic sebesar 5.610164 dan probabilitasnya bernilai 0.0000 . Nilai tersebut lebih kecil dari signifikansi $\alpha=0.05$ maka secara parsial, variabel angkatan kerja ber-pengaruh terhadap kesempatan kerja dengan arah koefisien regresi bernilai negatif signifikan. Dilihat dari nilai coefficient, variabel Angkatan Kerja ber-nilai -0.001628. Coefficient tersebut memiliki makna, ketika jumlah angkatan kerja di Jawa Tengah meningkat sebesar seribu jiwa dengan ketentuan bahwa PDRB dan UMP konstan maka tingkat kesempatan kerja di Jawa tengah akan menurun sebesar $0.001628 \%$. Hasil tersebut sesuai dengan hipotesis awal yang menyatakan bahwa angkatan kerja memiliki hubungan negatif signifikan terhadap kesempatan kerja sehingga hipotesis dinyatakan diterima.

Angkatan kerja memiliki pengaruh negatif serta signifikan terhadap kesempatan kerja, hal tersebut akibat dari meningkatnya angkatan kerja dari tahun ke tahun. Peningkatan tersebut akibat dari perekonomian Jawa Tengah yang relatif cepat berkembang se-hingga banyak masyarakat luar daerah khususnya luar pulau Jawa yang mencari pekerjaan di Jawa Tengah. Meningkatnya angkatan kerja juga dipengaruhi oleh sektor pendidikan karena pendidikan di Jawa
Tengah relatif maju dengan banyaknya perguruan tinggi atau sekolah tinggi terkemuka di Provinsi Jawa Tengah sehinga banyak pelajar maupun mahasiswa yang telah lulus menyelesaikan pendidikan dan mencari pekerjaan di Jawa Tengah sehingga menyebabkan kesempatan kerja menurun. Hasil penelitian ini sejalan dengan Sari, Musa dan Lestari (2017) dalam hasil penelitiannya yang mengemukakan bahwa di Kota Samarinda kesempatan kerja dipengaruhi oleh angkatan kerja secara negatif dan signifikan.

Variabel pertumbuhan upah mini-mum provinsi (UMP) memiliki nilai t-statistik sebesar 2.404106 dengan nilai prob sebesar 0.0236, nilai tersebut lebih kecil dari signifikansi $\alpha=0.05$ maka secara parsial, variabel pertumbuhan upah mini-mum provinsi memiliki pengaruh yang positif dan signifikan terhadap kesempatan kerja di Provinsi Jawa Tengah. Variabel upah minimum provinsi (UMP) memiliki nilai yang positif dan signifikan dihasilkan dari nilai coefficient sebesar 0.0044871 , nilai tersebut memiliki arti bahwa setiap kenaikan atau pertumbuhan UMP sebesar $1 \%$ dengan ketentuan PDRB dan angkatan kerja konstan maka kesempatan kerja di Jawa Tengah akan meningkat sebesar $0.0044871 \%$. Hasil ini sesuai dengan teori Neo-Klasik bahwa upah menjadi sebuah faktor penting dan berpengaruh terhadap penyerapan tenaga kerja dalam memperluas dan meningkatkan kesempatan kerja

Meningkatnya Upah Minimum Provinsi (UMP) tentu saja akan berdampak terhadap tingkat daya beli masyarakat, dikarenakan pendapatan yang diterima masyarakat menjadi lebih banyak maka, permintaan terhadap jumlah konsumsi masyarakat akan bertambah sehingga, perusahaan akan meng-hasilkan output yang lebih banyak. Ketika output perusahaan bertambah maka peru-sahaan akan membutuhkan atau meningkat-kan jumlah karyawannya sehingga, permin-taan terhadap tenaga kerja akan meningkat, dalam kata lain kesempatan kerja akan semakin besar. Hasil tersebut sejalan dengan teori penawaran dan 
permintaan tenaga kerja yang menyatakan bahwa ketika pasar kerja memiliki tingkat penawaran terhadap tenaga kerja tinggi, sedangkan permintaannya ren-dah maka tingkat upah akan mencapai titik yang rendah. Sebaliknya, dalam pasar kerja dimana jumlah penawaran terhadap tenaga kerja terbatas, sedangkan permintaan terhadap tenaga kerjanya tinggi, maka upah akan berada pada titik yang tinggi. Tingkat penawaran terhadap ahli ekonomi lebih tinggi daripada tingkat penawaran terhadap ahli akuntansi, meskipun tingkat permintaan terhadap mereka berada pada titik yang sama, para ekonom akan mendapatkan upah yang cenderung lebih rendah daripada ahli akuntansi. Hasil penelitian ini mendukung penelitian yang dilakukan (Dona et al., 2018) dimana upah minimum berpengaruh positif dan signifikan terhadap Kesempatan Kerja di Kota Samarinda. Penelitian lain yang juga sejalan yaitu penelitian Rahmawati (2014), dimana penelitiannya menunjukkan hasil yang menyatakan upah berpengaruh signifikan kearah positif dalam meningkatkan kesempatan kerja pada tahun 2002-2011 di Jawa Timur.

Uji F-statistik. Uji ini untuk mengetahui secara simultan pengaruh dari variabel independen yaitu PDRB, angkatan kerja dan laju Upah Minimum Provinsi terhadap variabel dependen yaitu tingkat kesempatan kerja. Hasil Uji F menunjukkan $\operatorname{Prob}(F$ statistic) memiliki nilai sebesar 0.000003, dimana nilai tersebut lebih kecil dari signifikansi $\alpha=0.05$ sehingga, model dalam pene-litian ini dinyatakan memenuhi kriteria good of fit maka, variabel Produk Domestik Regional Bruto (PDRB), angkatan kerja dan pertumbuhan Upah Minimum Provinsi (UMP) secara bersama-sama memiliki pengaruh terhadap kesempatan kerja di Provinsi Jawa Tengah artinya, Produk Domestik Regional Bruto (PDRB), angkatan kerja dan pertumbuhan Upah Minimum Provinsi (UMP) dapat memperluas kesempatan kerja di Jawa Tengah.

Uji Koefisien Determinasi $\left(R^{2}\right)$. Bertujuan mengetahui persentase keberpengaruhan atau derajat keakuratan di antara variabel independen terhadap variabel dependen. Dari hasil uji koefisien determinasi didapatkan nilai $R$-squared sebesar 0.655242 . Nilai $R$-squared sebesar 0.655242 memiliki arti bahwa variabel PDRB, angkatan kerja dan laju UMP memiliki pengaruhnya dan menje-laskan variabel tingkat kesempatan kerja sebesar $65.5 \%$ sedangkan $34.5 \%$ sisanya dipengaruhi dan dijelaskan oleh variabel lain yang tidak ada dalam model penelitian ini.

Dalam meningkatkan kesempatan kerja, negara dapat memberikan dorongan dalam bidang pertumbuhan atau peningkatan lapangan kerja dan meningkatkan kualitas tenaga kerja sehingga dalam pengelolaaan sumber daya daerah dapat dikelola oleh para tenaga kerja yang berkualitas (Giovanni \& Fadli, 2020). Dalam memperluas kesempatan kerja, instrumen kebijakan makro saja tidak cukup, namun juga membutuhkan sebuah perencanaan ketenagakerjaan yang komprehensif dan integral di antara struktur pasar kerja, meningkatkan kualitas pendidikan, serta instrumen kebijakan dalam sektor perekonomian maupun keuangan. Dalam perencanaan tenaga kerja, pada dasarnya memiliki dua penekanan, di satu sisi memuat perkiraan akan kebutuhan tenaga kerja dalam berbagai sektor, waktu maupun keahlian khusus (Permatasari, 2018).

\section{SIMPULAN}

Merujuk pada hasil pembahasan faktor-faktor yang berpengaruh terhadap kesempatan kerja di Jawa Tengah yaitu PDRB, angkatan kerja dan laju pertumbuhan UMP memiliki pengaruh terhadap kesempatan kerja di Jawa Tengah. PDRB dan laju pertumbu-han UMP secara parsial berpengaruh positif signifikan, artinya kenaikan PDRB dan UMP berdampak pada meningkatnya kesempatan kerja, sedangkan angkatan kerja memiliki pengaruh negatif, artinya kenaikan angkatan kerja akan menurunkan kesempatan kerja.

Seiring bertambahnya tenaga kerja setiap tahunnya, dalam meningkatkan laju pertumbuhan ekonomi serta pembangunan di Jawa Tengah maka, mendorong laju pere- 
konomian maupun pembangunan ekonomi dengan mendatangkan investasi yang berorientasi padat karya sehingga akan memperluas kesempatan kerja di Jawa Tengah. Selain dengan memperluas lapangan pekerjaan dan meningkatkan pertumbuhan ekonomi, me-ningkatnya jumlah tenaga kerja setiap tahunnya di Jawa Tengah harus diikuti de-ngan penetapan upah minimum secara tepat dan saling menguntungkan antara perusahaan (produsen) maupun karyawan (tenaga kerja) sehingga akan meningkatkan atau memperluas kesempatan kerja.

Meningkatkan kualitas tenaga kerja menjadi salah satu modal penting bagi setiap daerah dalam menjalankan dan meningkatkan pembangunan perekonomian baik dari segi pemasukan pajak, daya beli, maupun sebagai konsumen rumah tangga, sehingga laju pertumbuhan ekonomi regional semakin me-ningkat. Meningkatkan sumber daya manusia agar lebih produktif adalah langkah yang sangat penting disamping memperluas ke-sempatan kerja. Ketika kualitas sumber daya manusia meningkat, maka para tenaga kerja akan lebih berdaya saing dengan kualitas yang unggul melalui peningkatan kualitas pendidikan yang ada.

\section{DAFTAR PUSTAKA}

Alisman. (2018). Analisis Pengaruh Pertumbuhan Ekonomi dan Pengeluaran Pemerintah Terhadap Penyerapan Tenaga Kerja di Kabupaten Aceh Barat. Jurnal REP (Riset Ekonomi Pembangunan) volume 3 nomor 2(321333).

Atiyatna, D. P., Muhyiddin, N. T., \& Soebyakto, B. B. (2016). Pengaruh upah minimum, pertumbuhan ekonomi dan pendididikan terhadap penyerapan tenaga kerja di Provinsi Sumatera Selatan. Jurnal Ekonomi Pembangunan, Vol.14(1), 8-21. http:/ejournal.unsri.ac.id/index.php/jep

Badan Pusat Statistik. (1991-2021). Jawa

Tengah Dalam Angka. Badan Pusat

Statistik Provinsi Jawa Tengah.

Danawati, S., Bendesa, I. K. G., \& Utama,
M. S. (2016). Pengaruh Pengeluaran Pemerintah Dan Investasi Terhadap Kesempatan Kerja, Pertumbuhan Ekonomi Serta Ketimpangan Pendapatan Kabupaten/Kota Di Provinsi Bali. E-Jurnal Ekonomi dan Bisnis Universitas Udayana, 7, 21232160.

https://ojs.unud.ac.id/index.php/EEB/art icle/view/13030

Dona, D. R., Effendi, A. S., \& Muliati. (2018). Analisis Faktor-Faktor Yang Mempengaruhi Kesempatan Kerja. Forum Ekonomi, 20(1), 12-18. http://journal.feb.unmul.ac.id/index.php /FORUMEKONOMI

Giovanni, J., \& Fadli, M. F. (2020). Pengaruh Pertumbuhan Ekonomi Terhadap Kesempatan Kerja Di Kota Pontianak. Jurnal Ilmu Manajemen dan Akuntansi, 8(1), 10-17. https://jurnal.unitri.ac.id/index.php/refre nsi/index

Gujarati, D. N. (2012). Dasar-dasar Ekonometrika. Edisi Lima, Buku Dua. Penerbit Salemba Empat. Jakarta.

Herlina, E. (2016). Faktor-faktor yang Mempengaruhi Kesempatan Kerja Wanita dan Implikasinya terhadap Kesejahteraan Keluarga di Kabupaten Cirebon. Jurnal Ekonomi Program Pascasarjana Universitas Borobudur, 18(2), 172-207. https://ejournal.borobudur.ac.id/index.p $\mathrm{hp} / 1 /$ article/view/293

Hermawan, R., Indrawati, L. R., \& Sarfiah, S. N. (2017). Analisis Pengaruh Upah Minimum Provinsi (UMP), Investasi Terhadap Penyerapan Tenaga Kerja di Provinsi Jawa Tengah Tahun 20072017. DINAMIC: Direcrory Journal of Economic, $\quad 1, \quad 236-245$. http://jom.untidar.ac.id/index.php/dina mic/article/view/519

Kamilla, S., \& Hutajulu, D. M. (2021). Pengaruh Infrastruktur Terhadap Pertumbuhan Ekonomi di Provinsi Jawa Tengah. Jurnal Sosial dan Ilmu Ekonomi, V(April), 169-179. http://e- 
journal.ummy-

solok.ac.id/ojs/index.php/jusie/

Mulyadi. (2003). Ekonomi Sumber Daya Manusia dan Sistem Kelembagaan. Penerbit PT. Rajagrafindo Persada, Jakarta.

Pangastuti, Y. (2015). Analisis Faktor-Faktor Yang Mempengaruhi Penyerapan Tenaga kerja Di Provinsi Jawa Tengah. Economic Develompemt Analysis Journal, $\quad 4(2)$. http://journal.unnes.ac.id/sju/index.php ledaj

Permatasari, C. L. (2018). Strategi Peningkatan Kesempatan Kerja Berbasis Potensi Wilayah. Jurnal Ecodunamika, $\quad 1 \quad$ No.2. http://ejournal.uksw.edu/ecodunamika/a rticle/view/1593

Pratama, D. R., \& Hadiyanti, S. U. E. (2020). Pengaruh Produk Domestik Regional Bruto terhadap Kesempatan Kerja di Provinsi Kalimantan Timur. Borneo Student Research, 1(2), 800-805. http://journals.umkt.ac.id/index.php/bsr/ article/view/579/390

Purnamawati, D. L., \& Khoirudin, R. (2019). Penyerapan Tenaga Kerja Sektor Manufaktur Di Jawa Tengah 20112015. Jurnal REP (Riset Ekonomi Pembangunan), 4(1), 41-52. http://jurnal.untidar.ac.id/index.php/RE $\mathrm{P}$

Rahmawati, I. D. (2014). Pengaruh Investasi
Dan Tingkat Upah Terhadap Kesempatan Kerja Di Jawa Timur. jurnal ekonomi perencanaan pembangunan, vol.1 no.4. http://ejournal.unesa.ac.id/index.php/jup e/article/view/3582/6185

Saputra, T. F., Rajuni, D., \& Sukiman. (2021). Faktor-Faktor yang Mempengaruhi Kesempatan Kerja di Provinsi Banten Tahun 2010-2019. Jurnal Ilmu Ekonomi, 11(1), 37-54. http://jurnal.untirta.ac.id/index.php/Eko nomi-Qu

Sari, L. M., Musa. A. D., \& Lestari. D. (2017). Pengaruh Tingkat Pendidikan Dan Upah Serta Jumlah Angkatan Kerja Terhadap Kesempatan Kerja. Jurnal Ilmu Ekonomi Mulawarman, Vol.2(4). http://journal.feb.unmul.ac.id/index.php/ JIEM/article/view/1778

Sugiharti, Rr. Retno., \& Kurnia, Akhmad Syakir. (2018). Gender Wage Gap and Education: Case In Indonesia's Labor Market. E3S Web of conferences 73, 11019 (2018).

Wahyuni, S. (2019). Faktor - Faktor Yang Mempengaruhi Kesempatan Kerja Pada Sektor Pertanian di Sulawesi Selatan. Jurnal iImu Ekonomi, Volume 2(1), 207-215.

https://jurnal.fe.umi.ac.id/index.php/PA RADOKS/article/view/141 